\title{
ЛІТЕРАТУРА
}

1. Алексеев П. В., Панин А. В. Философия / П. В. Алексеев, А. В. Панин. 3-е издание. - Москва: Проспект, 2005. - 604 с.

2. Дормидонтова В. В. История садово-парковых стилей: учебное пособие для вузов. - М.:

Архітектура - С, 2003. - 203 с.

3. Клейн Л. С. История антропологических учений. - СПб.: Изд-во С.-Петерб. ун-та, 2014.

$-744 \mathrm{c}$.

4. Королев К. Энциклопедия символов, знаков, эмблем / состав. К. Королев. - М.: Эксмо; СПб.: Мидгард, 2007. - 608 с.

5. Круть И. В., Забелин И. М. Очерки истории представлений о взаимоотношении природы и общества / Предисл. Б. С. Соколов, Р. С. Карпинская. - М.: Наука, 1988. - 416 с.

6. Ожегов С. С. История ландшафтной архитектуры: Краткий очерк. - М.: Стройиздат, 1993. $-240 \mathrm{c}$.

7. Рассел Б. История западной философии / Б. Рассел. - Москва: Миф, 1993. - Т. I. - 512 с.

8. Рой Маккалистер. Все о растениях в легендах и мифах. СПб.: ТОВ «СЗКЕО«Кристал»», 2007. -192 c.

9. Рошаль В. М. Полная энциклопедия символов / состав. В. М. Рошаль. - М.: АСТ; СПб.: Сова, 2007. -515 c.

10. Сладкова О. В. Полная энциклопедия знаков и символов / О. В. Сладкова. - иМ.: АСТ: Астрель, 2010. - 319 с.

11. Сокольская О. Б. История садово-паркового искусства: учебник для вузов. - М.: ИНФРА-М, 2004. - $350 \mathrm{c}$.

12. Фирсова М. В. История садово-паркового искусства: учебное пособие. - Новосибирск:

Золотой колос, 2014. - 96 с.

UDC 72.03 doi: 10.31650/2519-4208-2020-20-157-166

\section{DEVELOPMENT OF ANTIQUE COLONY CITIES OF THE BLACK SEA IN THE HELLENISTIC PERIOD}

Plahotny G., Candidate of Technical Sciences, Associate Professor of the Department Architectural Structures

Varych A., senior lecturer of the Department Architectural Structures e-mail: varich09@gmail.com,ID ORCID:0000-0001-6807-1479

Chub O., assistant of the Department Architectural Structures

Odessa State Academy of Civil Engineering and Architecture

Abstract: a brief description of the origins of historical and architectural education and the development of Greek colonial cities on the shores of the Black Sea (Pontus of Euxinus), who lived during the Hellenistic period. The analysis of the phenomena that influenced the formation of ancient colonial cities is carried out. This is due to the geological work of the sea changing the contours of the coast, as well as the influence of the Black Sea currents. This influenced the features of trade and economic relations of the colonial cities. Thus the shortest sea path was routed from Tauric Chersonesos to Kallatis and Hercules, which shortened the sea route by several times due to the associated current. The presence of deep bays created favorable conditions for sailors, which attracted Greek immigrants.

Architecture was an important factor of influence and a means of spreading Greek culture in policies and subordinate local areas. Urban development was similar to the construction of the 
Mediterranean ancient states, sculpture was widely used in the design of cities-policies, the order system of construction was used, the streets were clearly planned, the cities had a water supply and drainage system.

To select the area for founding the city, following necessary factors were taken into account: a bay convenient for the port; trade routes and deep fairways; fertile land and the availability of sources of drinking water; elevated place, taking into account defensive capabilities; the availability of building material; natural resources.

The Greeks in the metropolis laid the foundation for many important branches of science. They laid the foundations of geometry, mechanics and statics, which created the basis for the development of engineering science in the construction of harbors, cities, bridges, dams and other structures.

The Bosporan cities have never reached the level of large cities of Ancient Hellas in architectural decoration and urban planning; they were much smaller and poorer. Nevertheless, the local residents sought to immediately show that they were following the general Greek traditions both in religion and in the arrangement of cities.

In the construction of public and residential buildings, wall or post-beam systems were used. For the construction of buildings, immigrants used local building material: clay, raw brick and stone-shell rock. Burnt brick was used mainly for decorating the building. For the construction of galleries and porticoes, wooden structures were widely used.

The main decoration of the buildings was considered the classic Doric order. The ceiling was formed with the help of crossbeams - architraves supported by columns. At the end of the architraves, other beams were laid, at the ends of which triglyphs could be formed, at the top of which another crossbar was placed.

Roofs were usually gable, sometimes pent. The supporting elements were the beams on which the ridge beam and the supporting rafters rested. For roofing, marble or ceramic tiles were used.

Urban development was similar to the construction of the Mediterranean ancient states, sculpture was widely used in the design of cities-policies, the order system of construction was used, the streets were clearly planned, the cities had a water supply and drainage system. The cities were surrounded by ramparts of raw brick or natural stone with battle towers and fortified gates.

City temples (dwellings of the gods) were located on the heights of the city or in its central part. They were built on a three-stage stone platform, the front door was high double-winged, always strictly oriented to the east. Architecture was an important factor of influence and a means of spreading Greek culture in policies and in subordinate local areas.

Keywords: Pont Evksinsky, city-polis, architectural structures, antique construction.

\section{РАЗВИТИЕ АНТИЧНЫХ ГОРОДОВ-КОЛОНИЙ ЧЕРНОГО МОРЯ В ПЕРИОД ЭЛЛИНИЗМА}

Плахотный $\boldsymbol{\Gamma}$. Н., кандидат технических наук, доцент кафедры архитектурных конструкций

Варич А. С., старший преподаватель кафедры архитектурных конструкций e-mail:varich09@gmail.com, ID ORCID:0000-0001-6807-1479

Чуб О. А., ассистент кафедры архитектурных конструкций

Одесская государственная академия строительства и архитектуры

Аннотация: Краткое описание истоков историко-архитектурного образования и развития греческих городов-колоний на берегах Черного моря (Понта Эвксинского), обитавшихрасположенных здесь в период эллинизма. Проведен анализ явлений, которые повлияли на образование античных городов-колоний. Это связанно с геологической работой моря, меняющей контуры берегов, и черноморские течения. Это повлияло на 
особенности торговых и экономических связей городов-колоний. Так из Херсонеса Таврического был проложен кратчайший морской путь к Каллатису и Гераклесу, который в несколько раз сокращал морской путь из-за попутного течения. Наличие глубоких бухт создавало благоприятные условия для мореплавателей, что привлекало греческих переселенцев.

Архитектура была важным фактором влияния и средством распространения греческой культуры в полисах и в подчиненных местных районах. Градостроительство было схоже со строительством средиземноморских античных государств, в оформлении городов-полисов широко использовалась скульптура, применялась ордерная система строительства, улицы были чётко спланированы, города имели систему водоснабжения и водосбора.

Ключевые слова: Понт Эвксинский, город-полис, архитектурные конструкции, античное строительство.

\section{РОЗВИТОК АНТИЧНИХ МІСТ-КОЛОНІЙ ЧОРНОГО МОРЯ В ПЕРІОД ЕЛЛІНІЗМУ}

Плахотний Г. Н., кандидат технічних наук, доцент кафедри архітектурних конструкцій

Варич Г. С., старший викладач кафедри архітектурних конструкцій e-mail: varich09@gmail.com, ID ORCID:0000-0001-6807-1479

Чуб О. А., асистент кафедри архітектурних конструкцій

Одеська державна академія будівництва і архітектури

Анотація: Короткий опис витоків історико-архітектурного виникнення і розвитку грецьких міст-колоній на берегах Чорного моря (Понту Евксинського), що були розташовані тут в період еллінізму. Проведено аналіз явищ, які вплинули на виникнення античних містколоній. Це пов'язано з геологічною роботою моря, яка змінює контури берегів, та чорноморські течії, що вплинуло на особливості торгових і економічних зв'язків містколоній. Так з Херсонеса Таврійського був прокладений найкоротший морський шлях до Каллатіса і Гераклеса, який в кілька разів скорочував морський шлях через попутні течії. Наявність глибоких бухт створювала сприятливі умови для мореплавців, що привабило грецьких переселенців.

Архітектура була важливим фактором впливу i засобом поширення грецької культури в полісах і в підкорених місцевих районах. Містобудування було схоже 3 будівництвом середземноморських античних держав, в оформленні міст-полісів широко використовувалася скульптура, застосовувалася ордерна система будівництва, вулиці були чітко сплановані, міста мали систему водопостачання і водозбору.

Ключові слова: Понт Евксінський, місто-поліс, архітектурні конструкції, античне будівництво.

Formulation of the problem. The concept of "antique" (from the Latin. antiqus - ancient) was introduced by Italian Renaissance philosopher scientists and combines a common name for Greco-Roman culture, which was considered the oldest at that time. Traces of ancient architecture are found on the islands of the Aegean, on the mainland of modern Greece, on the western coast of Asia Minor and on the island of Crete, on the northern part of Africa, whose population was closely related to the ancient Greeks and Romans.

Analysis of recent research and publications. Epy Greek colonization of Ukraine, main periods and stages of general historical development of the Hellenic community in the Northern Black Sea region are covered in [1, p. 17-18, p. 92-93, p. 122-123]. Materials on the emergence and development of Greek cities-colonies on the shores of Pontus of Euxinus: Olbia, Chersonesos, 
Panticopaeum and others are reflected in [2, p. 7-13]. The question of the historical and socioeconomic development of the ancient states that existed for almost a thousand years in the south of modern Ukraine is considered in [3, p. 35-70; 4, p. 30-35; 72-95]. The specific features of the antique coast of the Black Sea, taking into account the geological work of the sea and sea coasts, are studied in [5, p. 41-45; 62-78; 6, p. 14-25].

Purpose of the study: tobriefly systematize the history of the development of the Black Sea region, rooted in antiquity.

Research Objectives: 1. to analyze the degree of colonization of the shores of the Black Sea by the Greek cities-colonies during the Hellenistic period; 2. to identify the influence of Greek culture and architecture on the further development of the cities of the Black Sea region.

Presentment of the main material. The analysis of a comparison of the ancient architecture of Hellenism with modern architecture, art and culture. The research results are confirmed by archaeological excavations, as well as finds on the seabed.

In the period from 8 to 4 century BC.in ancient Greece, the political order and way of life were gradually changing. This contributed to the formation of Greek colonies-policies on the Black Sea coast. The reasons for the migration of the Greeks were overpopulation, a change in the state system, a decrease in land free for agriculture, and a decrease in the possibilities for selling and exchanging goods.

Before the formation of the policies of the coast of the Northern Black Sea Region, it was inhabited by separate tribes with different order of life. The fragmentation of the tribes served for the good good of the Greeks, so gradually they colonized the coast (VI-IV century BC.).

The Antique Black Sea sailing directions is a detailed geographical description of its coast, islands, changes in the sea coastline, water level and their movement, navigation features and hydrometeorological conditions of the water area, dangerous navigation zones and optimal approaches to ancient ports.

In the west, the Black Sea borders the Balkan Peninsula, in the north - the East European Plain, in the east - the Caucasian coast and the Colchis Lowland, in the south - the coast of Asia Minor. The coastline is $4090 \mathrm{~km}$.

Colony cities of the ancient Greeks were known throughout the ancient world as large seaports, military fortresses, and shopping centers. Trade routes connecting the wild North and East of that world with the Hellenic West of ancient Greek and Byzantine culture crossed here.

Four economically, culturally and commercially-developed centers of Greek settlements arose, which were famous for their rich reserves of ship and building wood, iron ore, various raw materials, and especially fishery.

The first is the coast of the Dnieper-Bug and Berezansky estuaries. Natives of the Greek city of Miletus in the late VII - early VI century BC.have founded on the bank of the Bugsky estuary the city of Olvia (now the village of Nerutino, near Ochakovo), one of the largest cities colonies, located between the Black Sea and the steppe, where the warlike tribes of nomads Scythians and Sarmatians - lived. Over time, the inhabitants of Olvia have established beneficial relations with these tribes. Olvia became a slave republic, independent of its metropolis.

The second is the vicinity of the Dniester estuary and the city of Tire (now the city of Belgorod - Dniester), as well as the city of Nikoniy, located on the territory of the present Ovidiopol district.

The third is the South-West of the Crimean Peninsula with the city of TauricChersonesos (the territory of modern Sevastopol).

The fourth center of ancient culture on the Northern Black Sea coast were the cities: Theodosius, Panticapaeum, located on the East Coast and the settlement of Phanagoria, on the Taman Peninsula (fig. 1).

The immigrants maintained close ties with each other, established relations with local tribes. Peaceful times alternated with military clashes. 
To select the area for founding the city, following necessary factors were taken into account: a bay convenient for the port; trade routes and deep fairways; fertile land and the availability of sources of drinking water; elevated place, taking into account defensive capabilities; the availability of building material; natural resources.

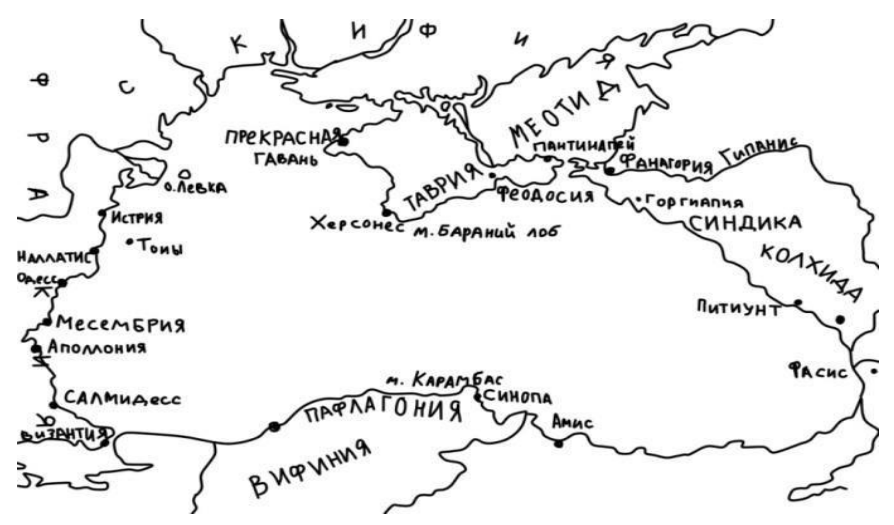

Fig. 1. Pontus Euxinus

Favorable geographical position in many respects determined further development. Greek city-policies in the socio-political structure were different among themselves: with unique urban planning and culture, developed crafts and agriculture. There was a significant influence of Greek culture on local tribes. Luxury goods, especially weapons, were especially respected by the local population. They were obtained in the course of natural exchange for cattle and slaves, or were taken by force from the Greeks.

The Bosporus Cimmerian kingdom belonged to the Greek settlements - lands near the Kerch Strait, with the capital of Panticapaeum (now the city of Kerch). In the process of development of policies, they united into a kingdom (approximately IV-V century A.D). The kingdom extended east to present Novorossiysk, north to Tanais, south to Theodosia.

The Greeks in the metropolis laid the foundation for many important branches of science. They laid the foundations of geometry, mechanics and statics, which created the basis for the development of engineering science in the construction of harbors, cities, bridges, dams and other structures.

Archaeological excavations on the top and terraces of the acropolis (modern Mount Mithridates) allowed to establish that in the second quarter of the VI century BC. the first colonists arranged here for themselves temporary dwellings such as semi-dugouts. However, the rapid expansion of economic activity and the political organization of the policy contributed to the fact that the Pantapapans began to build, however small, but houses made of stone. In the second half of the VI century. BC. there was progress in the development of construction and improvement of public services. In the last third of the VI century BC.on the upper plateau of the hill, the central temenos was highlighted, on which order buildings were built. Late archaic monumental public buildings were also discovered on Mount Mithridates, including a building with a rare layout - a tolos, in which, in all likelihood, there was a pritane. Tolos (Greek: "dome") is one of the most important public buildings, a dome-shaped building with a diameter of about 18 meters. The building had six columns inside, three in the east and three in the west to support the ceiling and a portico on the eastern facade, added in the 1 st century BC.

The head place in the trade of Nymphaeum was taken by the harbor. This is one of the few Bosporan cities where the stone construction of residential buildings and places of worship has reached a large scale as early as the VI century BC.

The Bosporan cities have never reached the level of large cities of Ancient Hellas in architectural decoration and urban planning; they were much smaller and poorer. Nevertheless, the 
local residents sought to immediately show that they were following the general Greek traditions both in religion and in the arrangement of cities.

This was shown especially vividly in the construction of temples and altars. Very small in size, they, as can be seen from the architectural and construction remains in Panticapaeum and Nymphaeum, had an Ionian order, covered with a tiled roof. The capitals for the columns were made of local limestone, exactly copying Miletus. In the second half of the VI century BC.the Bosporus architects had not yet had the opportunity to build large stone temples for their guardian gods. Usually only the basement was built of stone, the walls were raw, the floors, and sometimes the columns, were wooden. But the "dwellings of the gods" were often copied from those temples that already stood in the metropolis.

Around the middle of the V century BC.the monumental temple of Apollo Ietros was built in Panticapaeum (fig. 2). The preserved architectural details that made it possible to carry out its reconstruction give the right to classify it as the most ambitious religious buildings of that time on the scale of the Black Sea. Most likely, such a temple was considered by the Hellenes as a symbol of religious and political association, thanks to which a decisive victory was achieved over the nomads. The construction of the temple, which required significant costs, the construction of residential buildings decreased. Apparently, the main resources went to the construction of the defensive line and the temple.

In the second half of the IV century BC.there was a constant expansion of the urban development of Panticapaeum due to population growth. And along with this, they began to pay great attention to improvement of public services. There were many wells, drains, including sewers. Residential buildings were becoming more spacious. The interior of some of them were decorated as in the rich Greek houses of Athens. The walls were plastered and painted in different colors, and often painted.

The houses of wealthy residents were built with a colonnade of porticoes in the Doric and Ionic order style. The same orders were used in the construction of temples. In many houses of Panticapaeum, Phanagoria, Nymphaeum and other cities at that time, the construction of andron, a room for the owner, was mandatory. The floors were often covered with mosaics [1, p. 82-83].

In the construction of public and residential buildings, wall or post-beam systems were used. For the construction of buildings, immigrants used local building material: clay, raw brick and stone - shell rock. Burnt brick was used mainly for decorating the building. For the construction of galleries and porticoes, wooden structures were widely used.

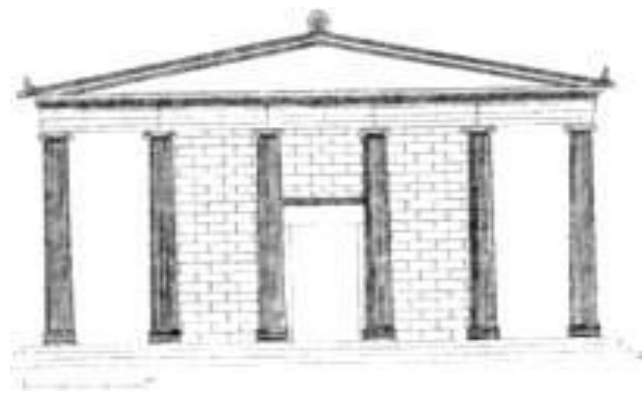

Fig. 2. The Temple of Apollo in Panticapaeum (scheme by I. P. Pichikyan)

The main decoration of the buildings was considered the classic Doric order. The ceiling was formed with the help of crossbeams - architraves supported by columns. At the end of the architraves, other beams were laid, at the ends of which triglyphs could be formed, at the top of which another crossbar was placed. Roofs were usually gable, sometimes pent. The supporting elements were the beams on which the ridge beam and the supporting rafters rested. For roofing, marble or ceramic tiles were used. 
Urban development was similar to the construction of the Mediterranean ancient states, sculpture was widely used in the design of cities-policies, the order system of construction was used, the streets were clearly planned, the cities had a water supply and drainage system. The cities were surrounded by ramparts of raw brick or natural stone with battle towers and fortified gates.

City temples (dwellings of the gods) were located on the heights of the city or in its central part. They were built on a three-stage stone platform, the front door was high double-winged, always strictly oriented to the east. Architecture was an important factor of influence and a means of spreading Greek culture in policies and in subordinate local areas.

Comprehensive studies of geologists, historians, archaeologists, and many other experts have made it possible to determine that during the so-called Fanagori regression, the Black Sea level was at least $6 \mathrm{~m}$ lower than the current water level (in the V-III century BC). For example, part of the city of Phanagoria was flooded with a subsequent increase in sea level. In the 1st millennium, the sea level, apparently, was approaching modern. In the XIV-XV century AD. regression followed again. Then a new rise in sea level began. Because of this, many ancient cities ended up under water.

Attention should be paid to the geological work of the sea. A huge mass of moving water does a great job of destroying the coasts, as well as accumulating the destroyed material and forming new rocks and minerals. The main factor in the destruction of the sea coast is the shock force of the wave. It breaks strong rocks, moves them over long distances.

In the Black Sea, there is its own closed ring of the stream with a width of 20 to 50 miles, passing 2-5 miles from the coast counterclockwise. In the southern vicinity of Crimea, the current is divided. The main course goes north, to the mouth of the Dnieper-Bug estuary, and part of it goes to the Danube shores. Having accepted the Dnieper, Bug, and then the Dniester waters, the flow goes to the Bosphorus. The main part of the course, having given part of the waters to the Sea of Marmara, turns to Anatolia. Prevailing winds favor eastward traffic. Further, one branch of the current goes north to the Crimea, and the other continues to move east, absorbing the waters of the rivers of Asia Minor. Near the Caucasian coast, the current turns to the northwest, near the Kerch Strait, it merges with the Azov Current. On the southern coast of Crimea, division again occurs, closing the East Black Sea circle. The Anatolian current closes the West Black Sea circle. In ancient times, the rivers were full-flowing, the currents were more intense, influencing the navigation and development of short trade sea paths (fig. 3) [5, p. 41-78].

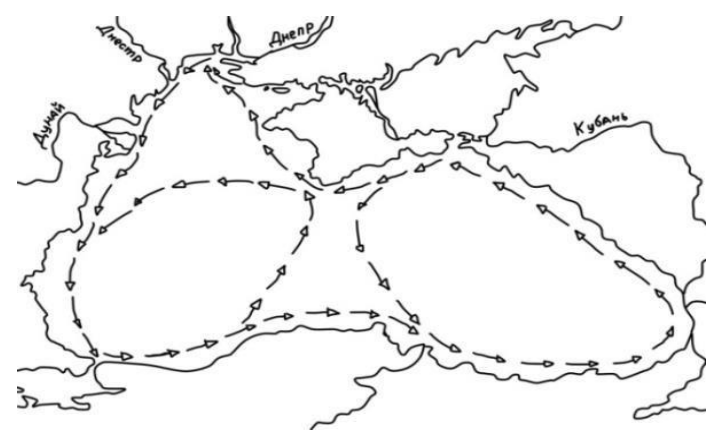

Fig. 3. Scheme of the main currents in the Black Sea

Due to the flooding of some areas of the land with the subsequent retreat of the sea from them, the coastal soils have complex bedding with the inclusion of silt and other alluvial and deluvial soils. Special sediment deposits formed in the thalweg of ancient rivers. Such wide terraces and floodplains covered the mouth of the rivers Istria (Danube), Tirasa (Dniester), Gipanisa (Southern Bug), Borisfena (Dnipro). At that time, during heavy rains, a large amount of silt accumulated in the mouths of these rivers. Smoothly flowing rivers formed large braids of silt, especially at the mouths of shallow estuaries. 
The Kirnburg sand tongue forming the peninsula was located on the territory of modern Kherson and Nikolaev regions. The ancient Greek traveler Herodotus described it as a narrow sandy tongue that separated Black Sea from the Dnieper-Bug estuary. In ancient times there was a temple for the goddess of fertility Demeter. This temple was later destroyed.

In the southern Black Sea region, the population was more stable. Among the cities stood the city of Heracles, which closed the sea trade route of Tauric Chersonesos - Kallatis - Heracles. The cities of Sinop, Atis, Trebizond, Kateora are also known. They had both marine and defensive significance.

The eastern part of the Black Sea region was unfavorable for dense settlement due to the mountainous terrain and the presence of hostile tribes there.

The city of Fasis with the special properties of water was laid in Colchis. On the territory of one of the best bays of the Eastern Black Sea coast - Sukhumskaya, the city of Dioskuriada was founded. In the middle of the VI century BC.the city was located on a cape 5-6 km wide with adjacent lowlands. Due to its favorable geographical position, the city grew and developed rapidly. However, marine soil erosion led to flooding of a significant part of the city by 6-8 meters under water. In 1953, at a depth of $5 \mathrm{~m}$, a marble tombstone was discovered. It depicts a scene of farewell to the deceased. This stele is a huge find, allowing us to learn more about ancient art. The territory that surrounded the city of Dioskuriada consisted of high steep banks, the absence of convenient bays and bays, the lack of fertile soil, and hostile local tribes prevented the appearance of a large number of ancient cities.

On the north-eastern coast of Pontus of Evksinsky, Gorgippia (Anapa) and Phanagoria should be highlighted (today ruins are preserved, the area occupied by the settlement is up to 60 hectares), located in the lowland floodplain of the river Giponis (Kuban). These cities were economically connected with Panticapaeum (Kerch), located at the mouth of Meotida (Sea of Azov).

Greek colonial cities based on the southern and western parts of the Crimean peninsula had an important role in the socio-political life of the entire coast of Pontus Euxinus. A short sea path was routed from TauricChersonesos to Kallatis and Hercules, which reduced the time spent en route by a factor of three due to the location of the current (fig. 3). Khersones was located on a vast cape in the modern Quarantine Bay [6, p. 14-25]. The presence of deep bays created favorable conditions for sailors, this attracted Greek immigrants. In Chersonesos there was a temple of the Virgin Goddess, she was the supreme patroness of Tauric Chersonesos and was depicted on coins.

The city of Kerkinida (Evpatoria) was founded in the VI century BC. on the Quarantine cape. The further fate of the city was connected with the Kherson kingdom and in close relationship with the Scythians. The adjacent lakes were saturated with healing salts (the system of Saki lakes). In the vicinity of Yevpatoriya, the ruins of the sanctuary of Achilles were found. In ancient times, coniferous forests grew in the vicinity of Kerkinida, in the alluvial sand from Borisfen there were inclusions of quartz used for the manufacture of glass products.

The city of Kafa (later the city of Feodosia) had a favorable geographical position, proximity with busy sea routes, a beautiful harbor, and fertile flat lands. This has given the city rapid development and prosperity.

The city of Olvia - one of the largest ancient cities, was located on the right bank of the Bug estuary. Its existence is closely intertwined with the Scythian, Sarmatian and Getofraki tribes. Located on the sea, the island of Berezan at a sea level lowering of $5 \mathrm{~m}$ was a peninsula with a convenient harbor.

On Ponte Evskinsky there were two ancient cities, called Odesos. One of them was on the left bank of the mouth of the Tiligul estuary. As a result of marine erosion, the city was gradually destroyed by the sea. The same fate befell the settlements in Dofinovskaya and Kryzhanovskaya beams.

In the northern Black Sea region, the most convenient was the bay much later called Odessa, which was the most convenient and safe for ships in all of Ponte Evskinsky. Here two 
straits merged into one wide bay: Issiakov and Istrian. And in the depths in the middle of the spill there was a sloping elevation (modern Zhevakhov Mountain). On the mountain itself, the village of Ginestra was founded, then trading with Athens agricultural products, cattle, wine, fish and salt.

The second city of Odesos was located on the site of the modern Bulgarian city of Varna.

The city of Nikoniy was located on the banks of the Tiras River (the modern territory of the village of Roksolany, Ovidiopolsky District, Odessa Region), later it was flooded by the modern Dniester estuary, formed from the branches of the Tiras River (now the Dniester River). At the mouth of the river between its arms was the Neopteläme Tower - a lighthouse indicating the entrance to the fairway of the river, its tower now completely destroyed.

Opposite the Burnas cape (Lebedyovka village) at a depth of 3-5 meters at the bottom of the sea, traces of the city's architectural structures destroyed by the sea were revealed.

The sacred island of Achilles - the island of Levka was famous among the then sailors. On the island was the temple of Achilles. It was forbidden to build any settlements on it, the island was under the auspices of Olbia. In the Middle Ages, the temple was abandoned and forgotten. The island received a new name - Fedonis (Serpentine). At the base of the temple there were natural caves, where priests of the temple hid valuables during pirate raids.

The city of Istria was founded in the delta of the Istria River (Danube River), which had six separate estuaries. Istria was a major trading hub. Over time, the riverbed left the city and it lost its significance. In the Middle Ages the mouth was called St. George's, in the XVIII century Sulinsk, now - Kiliysk mouth.

In all of the above cities, the Greeks widely used their own architecture to assert their influence. Greek architects searched among the surrounding world for the most harmonious forms and, finding them, embodied in buildings and structures. The buildings were distinguished by a clear strict compositional rhythm, aesthetically significant in creativity.

Modern excavations indicate the location of other colonial cities on the shores of the Northern Black Sea coast.

It should be noted that as far back as the III-I centuries BC. during the period of the Roman Empire, the legionnaires did not ignore the northern Black Sea coast, from the mouth of Istra (Danube) to Olvia, including these lands in the province of Moesia. Roman influence spread to the Bosporus kingdom, but turmoil inside the empire forced to leave the lands of the Black Sea and Crimea in 40-30 years of the III century BC.

Sarmatians also visited these lands (III-I centuries BC). The associations of nomadic pastoral tribes that left the Volga steppes gradually replaced the Scythians, forming Sarmatia. These warlike people successfully fought against the Bosporus kingdom and the Romans. To protect their lands from the nomads, the Romans built a powerful citadel on the banks of Istria (Danube River) and earthen fortifications - Troyanovsky ramparts. The Istria River has become the natural border of the Roman Empire. On the outskirts of modern settlement Orlovka of the Rheni district the Stone Mountain was built - an impregnable fortress with walls a meter and a half thick, made of large stone blocks. It was one of the chain of fortifications - fortresses, the socalled Danube Limes. For more than three hundred years, the domination of the Romans in Lower Moesia continued. But in the third century AD, their dominance weakened due to economic and political strife. The Sarmatian tribes took advantage of this and dealt a crushing blow to the legionnaires, which led to the defeat of the former. In the IV century AD the main Greek cities the colonies, the Bosporus kingdom, the local Sarmatian tribes were swept away by the invasion of the Goth tribes from the North, and from the East by the Huns. The Huns are a warlike tribe of nomads from Central Asia, oppressed by the Chinese Empire since the I century AD. On their way, the Huns set fire to everything that could burn. And thus, the civilization brought by the Greeks to the shores of Pontus Euxinus in the 4th century BC was destroyed.

\section{Conclusions.}

1. During Hellenism, the shores of the Black Sea were actively inhabited by ancient Greek colonists. The emergence and development of cities-colonies more than 2500 years ago is caused 
by the presence of deep bays off the coast and the location of sea currents, which contributed to the creation of a sea trade route. Later, on the site of ancient Greek policies, new cities arose and developed - cities which even in our time are still considered to have a developed port structure.

2. Archaeological details and elements found both during excavations and on the seabed indicate further influence of Byzantine culture on the appearance and traditions during the creation offuture cities of the Black Sea region on this territory, enriching them with elements of Greek culture and eastern traditions.

Bearing elements of double-pitch roofs, erected in the cities of the Northern Black Sea region since the time of the ancient Hellenes, are relevant and applicable in modern construction. The use of local building materials - clay, raw bricks, limestone and fired clay bricks - continued for many centuries and still continues today. The wall or post-and-beam systems introduced by the ancient Greeks into construction have been used ever since those times.

Research prospects. Studying the architectural and constructional features of the structures in ancient Greek policies of the Northern Black Sea region after excavations done by archaeologists at insufficiently studied sections of cities located both on land and under water.

\section{LITERATURE}

1. Zubar V.M., Rusyaeva A.S. Na beregah Bospora Kimmerijskogo. - K.: ID Stilos, 2004. $-239 \mathrm{~s}$

2. Berezin A. A. Istochnikovedcheskij obzor pamyatnikov antichnoj epohi Severnogo Prichernomorya // Voprosy podvodnoj arheologii. - M.: Moskovskij podvodno-arheologicheskij klub, 2010. - S. 5-24.

3. Zubar V. M. Antichnij svit Pivnichnogo Prichornomor'ya: Narisi istorichnogo ta socialno-ekonomichnogo rozvitku: navch. posib. / V. M. Zubar, Ye. A. Linova, N. O. Son. - K.: Vidavnictvo im. O. Teligi, 1999. - $320 \mathrm{c}$.

4. Vahtina M. Yu., Vinogradov Yu. A., Marchenko K. K. Greki i varvary Severnogo Prichernomorya v skifskuyu epohu. - SPb.: Aletejya, 2018. - 464 s.

5 Taskaev V. N. Antichnaya podvodnaya arheologiya Severnogo Prichernomorya. - M., 2009. - $176 \mathrm{~s}$.

6. Bukatov A. A., Bondarev I. P. Geologicheskie processy i razrusheniya pribrezhnyh gorodskih kvartalov Hersonesa v rajone XXVIII i XXIX kurtin oboronitelnoj linii u zapadnogo berega Karantinnoj buhty // Voprosy podvodnoj arheologii - M.: Moskovskij podvodnoarheologicheskij klub, 2017. - S. 13-29.

УДК 72.03:101 doi: 10.31650/2519-4208-2020-20-166-178

\section{ФИЛОСОФИЯ И АРХИТЕКТУРА ЧАЙНЫХ ДОМИКОВ ЯПОНИИ}

Польщикова Н. В., канд. архитектуры, доц. каф. ДАС

Ковбасюк Н. В., магистр архитектуры

Одесская государственная академия строительства и архитектуры

Аннотация: Рассмотрена история развития чайной церемонии в Японии начиная с XII века, когда из Китая в Японию пришел способ приготовления чая. Появление чайных домов, их архитектура и внутреннее убранство (ниша-токонома, открытый очаг-ирори и т. д.), а также убранство сада (дорога летящих камней-родзи, чаша для омовения). Чайная церемония, пройдя сквозь века, нашла отражение не только в философии, но и в архитектуре, продолжая развиваться, сохраняя при этом традиционный вид. Стремление 